\title{
Is it possible to raise, offspring of the 25th generation of Litopenaeus vannamei (Boone) and 18th generation Litopenaeus stylirostris (Stimpson) in clear water to $\mathbf{4 0} \mathrm{g}$ ?
}

\author{
Gérard Cuzon ${ }^{1, *}$, Leticia Arena ${ }^{2}$, Jean Goguenheim ${ }^{1}$, Emmanuel Goyard $^{1}$ \& Aquacop ${ }^{1}$
}

(1)Laboratoire d'Aquaculture Tropicale, IFREMER, BP 7004, 98719 Taravao, Tahiti, French Polynesia.

(2)Laboratorio de Ecophysiologia, UNAM, Playa Norte, Cd del Carmen, Campeche, Mexico.

*: Corresponding author : gcuzon@ifremer.fr

\begin{abstract}
:
Peneid shrimp are commonly reared in clear-water aquaria or tanks for short-term studies of 46 weeks during controlled experiments, such as nutrition studies to estimate dietary nutrient requirements. Recently, in line with the genetic program at Centre Océanologique du Pacifique (COP), experimental clear-water facilities were tested for the first time over a longer rearing period. Environmental conditions used to maintain animal growth in clear-water system using a well-balanced diet were defined. After 100 days, shrimp growth rates tended to decrease and only by adjusting the diet could shrimp complete their life cycle and reach maturation size of around $40 \mathrm{~g}$. This paper presents information on stocking density, diet quality and husbandry linked to reproduction that must be considered to successfully rear animals from PL's to breeder size in clear water. By following these protocols a minimum amount of breeders can be used to meet production goals. Moreover, by isolating a small group of individuals, genetic diversity can be preserved, thereby allowing specific crosses for selective breeding purposes. Length of trials, amount of feed, composition of feed, growth performances and maturation success are reported and should encourage further studies to optimize rearing conditions in clear-water rearing.
\end{abstract}

Key words: shrimp; Litopenaeus stylirostris; quarantine; husbandry; formulated diets

Mots clés: crevette; Litopenaeus stylirostris; quarantaine. zootechnie, nutrition 


\section{Introduction}

Several commercial domesticated strains of shrimps have been developed in the world;: in Hawaii (Wyban, Martinez \& Sweeney 1995), in Venezuela (Persyn pers. com 1995) and in Tahiti (Weppe, Bonami, Lightner \& Aquacop 1990). These strains are currently available to producers who want to take advantage of selective breeding programs developed elsewhere in the world. Since the 1980's, many diseases now affect the world shrimp farming industry (Mock 1977; Bachère, Miahle, Noel, Boulo, Morvan \& Rodriguez 1995) leading to biosecurity protocols for risk management and regulations to improve the outlook of sustainable culture of non-indigenous shrimp.

Although some commercial strains are said to be specific pathogen-free (SPF) thanks to zoosanitary controls at each generation, the risk of introducing an unknown pathogen cannot be ignored. For this reason, some pathologists consider that the recommendations of ICES about the transfer of living marine animals should always be followed independently of the status of the animals. In other words, introducing new strains in a given country would necessitate the rearing and reproduction of one generation of shrimp in quarantine facilities. This may become a real challenge not only in New-Caledonia, but also in all countries where shrimp industries are developing.

New Caledonian and Polynesian shrimp production is based on closed populations of Litopenaeus stylirostris broodstocks. This species was introduced from Latin America several times between 1970 to 1980 as a candidate species for aquaculture. Nevertheless, the shrimp populations in New-Caledonia to have experienced several problems during the early phases of their introduction when closing the life cycle in captivity was problematic. This limitation can explain the low level of genetic variability found in New-Caledonia and in Tahiti shrimp broodstock populations (Goyard, Arnaud, Vonau, Bishoff, Mouchel, Pham, Wyban \& Boudry 2003). Thus these domesticated populations were exposed to the risk of being unable to respond to new selective pressures due to controlled or uncontrolled changes in the environment. For example, a relatively low heritability for growth rate (around 15\% ) was obtained in a selective breeding program on the Tahitian strain, which is genetically close to the New-Caledonian one (Goyard, Patrois, Peignon, Vanaa, Dufour, Viallon, Bedier 2002). Increasing production in New-Caledonia with $500 \mathrm{mt}$ in 1990 (Ottogalli Galinié \& Goxe 1998), 2000 metric tons in 2000 and with a goal of 5000 metric tons in 2005, certainly can justify the development of new approaches, such as genetic improvement to sustain yield, whose efficiency will depend on the genetic variability of the populations under selection (Moss, Otoshi, Arce, Argue, Montgomery, Nagamine \& Zogbi 2001). Introduction of genetic variability appears as a long term requirement under these circumstances even if the populations of New-Caledonia do not show signs of depression in performance and currently demonstrate high productivity $(4.7 \mathrm{mt} / \mathrm{ha} /$ cycle in aerated ponds, $3.5 \mathrm{mt} / \mathrm{ha} /$ cycle in non aerated ponds; Lucien-Brun 1997).

Two strategies can be used to rear shrimp in quarantine from the larval stage (Aquacop 1977) to maturation and spawning. (Harrison 1990; Lytle, Lytle \& Ogle 1990). The first approach is to re-create in a confined area an ecosystem that mimics optimal growth for the shrimp in outdoor earthen ponds. In this system, shrimp can benefit from natural productivity, e.g. development of benthic organisms under low stocking density with little grazing pressure. In this habitat, organic particles colonized by bacteria remain available for grazing during the course of broodstock maintenance. Although from a quantitative point of view, this source of nutrition appears negligible, it represents an important source of nutrients that are not provided 
by dry feed. This reliance of natural productivity is particularly true for the post larvae during the first month or during the nursery phase (Otoshi, Montgomery, Look \& Moss 2001). It has been suggested that grazing can compensate for a low $(45 \%)$ protein feed. The other option is to rear the shrimp in clear recirculated water where all the requirements of the different life stages are satisfied by an artificial diet. IFREMER has developed a wide knowledge of recirculation system design for fish culture (Blancheton 2000). This concept can be used for grazing shrimp as long as all life stages (e.g., post larvae to adult) can be reared in clear water on a full cycle. Furthermore, this approach could also have some applications in the testing of the animal performance under strictly controlled conditions, e.g. testing of selected genetic strains, and conducting physiology and immunology trials.

Several authors have successfully reared using commercial diets in clear water for short periods, penaeid shrimps such as $L$. vannamei from nauplii up to one gram weight, whereas Penet, Goyard, Chim, Cuzon, Bureau, Bédier \& Aquacop (2001) and Dao, Goyard, Cuzon, Bureau, Seynave \& Aquacop (2002) reared subadults of L. stylirostris for 4 weeks and obtained growth rates of $0.15-0.20 \mathrm{~g}_{\text {day }^{-1}}$. More generally, 25\% per week weight increase is recorded when they are small, 30\% per week when shrimp reached up to $4-5 \mathrm{~g}, 20 \%$ per week to grow to $12 \mathrm{~g}$ and $15 \%$ per week to gain marketable size of $20 \mathrm{~g}$ or more. Unpublished results from a clear-water trial at Centre Océanologique du Pacifique (COP Tahiti, French Polynesia) suggested that rearing shrimp in clear water for a longer period resulted in limited success; after 100 days, growth of shrimp fed a commercial diet leveled off in clear water. Modifications to the diet was required for the shrimp to reach spawning size, and complete their lifecycle with relatively poor reproductive performance. The objective of this study was to optimize rearing densities and feed formulation to allow L. stylirostris and L. vannamei to be reared to spawning in a clear water system.

\section{Material and methods}

\section{General rearing conditions}

Three experiments were conducted at IFREMER in indoor facilities at Centre Océanologique du Pacifique (COP/Tahiti). The studies were conducted in small fiberglass square flat-bottom tanks $\left(0.5 \mathrm{~m}^{2}\right.$ and $\left.1.2 \mathrm{~m}^{2}\right)$. These tanks were selected for three reasons: (1) small tanks facilitate daily maintenance and control, (2) their small capacity allows quick exchange in case this was required to maintain adequate water quality, and (3) small tanks permit the shrimp population to be divided into several genetically different strains in order to handle introduced genetic variability properly.

In all studies, lagoon water was sand filtered and used in a "single" pass with a water renewal rate of between 50 and $100 \%$ per hour. Characteristics of the lagoon water were as follows: $27^{\circ} \mathrm{C}$ and $35 \mathrm{ppt}$; a minimum of $6 \mathrm{ppm} \mathrm{O}_{2}$ always near saturation, $\mathrm{pH}=8.2$; nitrates, $0.3 \mu \mathrm{gl}^{-1}$,

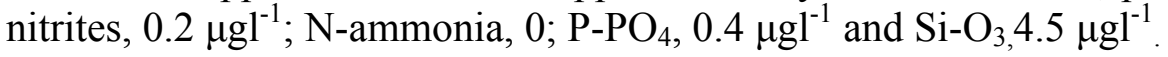

Oxygenation in indoors tanks was provided by an aerator. Photoperiod was $10 \mathrm{hr}$ light in July and $14 \mathrm{hr}$ in December and additional light (more intensity) was provided using day-light fluorescent tubes (100 lux). 
Formulated artificial pellets (Table 1) were distributed manually 3 times a day. There was no special care to calculate feed conversion ratio (FCR). Rearing tanks were cleaned every day to remove faeces and uneaten feed.

Table 1. Formulated diets composition $\%$ as fed (made in COP or imported) for L. stylirostris and L.vannamei breeders.

\begin{tabular}{lccc}
\hline & $\begin{array}{c}\text { imported } \\
\text { feed g/kg }\end{array}$ & $\begin{array}{c}\text { PGN } \\
\mathrm{g} / \mathrm{kg}\end{array}$ & $\begin{array}{c}40 \mathrm{ne} \\
\mathrm{g} / \mathrm{kg}\end{array}$ \\
\hline $\begin{array}{l}\text { Norseamink FM } \\
\text { soya bean meal }\end{array}$ & 400 & 430 & 130 \\
squid meal & 150 & 200 & 60 \\
mussel meal & & & 300 \\
wheat gluten & & 150 & 100 \\
lactic yeast & & & 120 \\
hard wheat & 300 & 120 & 100 \\
staple meal & 90 & - & - \\
vit mix ${ }^{(1)}$ & 10 & 20 & 20 \\
fish oil & 20 & 40 & 30 \\
lecithin & 10 & 20 & 20 \\
astaxanthin ${ }^{(3)} \mathrm{ppm}$ & - & - & - \\
minerals ${ }^{(2)}$ & 20 & 20 & 20 \\
& & & \\
moisture\% & 10 & 9 & 9 \\
protein\% & 43 & 55 & 58 \\
lipid\% & 8 & 10 & 10 \\
NFE & 27 & 14 & 9 \\
ash \% & 12 & 12 & 14 \\
DE kJ/g & 17 & 18 & 19 \\
\hline
\end{tabular}

${ }^{(1)}$ vit mix in pure substance /kg: A: $0.8 \mathrm{M} \mathrm{UI} / \mathrm{kg}, \mathrm{D}_{3:} 0.2 \mathrm{UI}$, E: $10000 \mathrm{UI}$; stay-C: $1 \mathrm{~g} ; \mathrm{B}_{1}: 0.07 \mathrm{~g}, \mathrm{~B}_{2}: 0.2 \mathrm{~g}, \mathrm{~B}_{6}: 0.1 \mathrm{~g}$, PP: $1 \mathrm{~g}, \mathrm{~B}_{12}: 0.7 \mathrm{mg}$, menadione: $58 \mathrm{mg}$, pantothenate $\mathrm{Ca}: 50 \mathrm{mg}$, acid folic: $4 \mathrm{mg}$, biotin: $0.4 \mathrm{mg}$, inositol:

$1.4 \mathrm{~g}$, choline, $3 \mathrm{~g}$

(2) minerals : $\mathrm{NaH}_{2} \mathrm{PO}_{4}, \mathrm{KH}_{2} \mathrm{PO}_{4}, \mathrm{MgCl}_{2}$ in $1 / 0.5 / 0.5$ proportion respectively.

(3) $\beta$-carophyl red (Hoffmann LaRoche) not added in the present study previously tried at $50 \mathrm{ppm}$.

${ }^{(4)}$ Soyabean meal with $1.88 \mathrm{mg} / \mathrm{g}$ of antitrypsic factor; but, antigens, glycinine (14 inhibition pits of hemaglutinin and $\beta$-conglycinine with 8 pits revealed a slightly high level.

${ }^{(5)}$ Native wheat gluten from Roquette frères, 62138 Lestrem, France:

(6) lactic yeast from Bel Industries, France;

${ }^{(7)}$ squid and mussel from MC Farlane, NZ.

\section{Experiment 1}

A total of 58, 150 day-old post-larvae (PL50) L. stylirostris individuals used in this experiment had been reared in clear water up to $13 \mathrm{~g}$ average weight for strain testing (Dao et al. 2002). At 200 days post-larvae, their average weight was $27 \mathrm{~g}$. To start experiment 1 , they were sexed and marked by injection of colored elastomer (Godin, Carr, Hagino, Segura, Sweeney \& Blankenship 1995) to individually identify each shrimp and then each was weighed. Shrimp were stocked in four $1.2 \mathrm{~m}^{2}$ tanks at two densities $\left(8-9\right.$ animal $/ \mathrm{m}^{2}$ and $\left.14-17 \mathrm{animal} / \mathrm{m}^{2}\right)$ to test the effect of stocking density on biological performance. 
Shrimp were fed an experimental diet ("special quarantine") whose formulation was similar to the maturation diet (Table 1) defined by Cuzon \& Aquacop (1998). Daily feed distribution rate was $10 \%$ of tank biomass so that the feed quantity would not limit growth. This ration was selected following observations on animals from the same batch which were reared in smaller tanks (Dao et al. 2002). Every fifteen days, all animals were individually identified and weighed and survival was determined. Concurrently, animals from the same larval rearing batch were reared following the standard protocols used by Aquacop. The protocol included 10 animals per $\mathrm{m}^{2}$ in outdoor earthen ponds, until animals weighed $20-25 \mathrm{~g}$. The shrimp were then transferred to $30 \mathrm{~m}^{2}$ shaded, fiberglass tanks at $30 \mathrm{shrimp} / \mathrm{m}^{2}$ until they reached $40-50 \mathrm{~g}$. These shrimp served as a control group in clear water. Water temperature ranged from $25-28^{\circ} \mathrm{C}, \mathrm{pH}$ was around 8.2 and salinity was $35 \mathrm{gl}^{-1}$. The only water quality variable was oxygen which dropped at night and increased during the day when phytoplankton concentration reached 400 000 cells $\mathrm{ml}^{-1}$.

At $\mathrm{Pl}_{320}$, the animals reared in clear water and their controls were transferred into $4 \mathrm{~m}^{3}$ tanks in a maturation room as described by Aquacop (1975). Females were eyestalk ablated to synchronize maturation. Males from clear water tank were mated with control females and vice versa in order to assess the effect of the clear-water reproductive performance. For each mating, number of eggs, fertilisation rate, number of nauplii and hatching rate were measured. These data were compared to standard performance of males and females from the same rearing source.

\section{Experiment 2}

A hatchery population of $L$. stylirostris was reared in outdoor $30 \mathrm{~m}^{2}$ tanks up to $1 \mathrm{~g}$. During this nursery phase, pre-growing conditions were as follows: $30 \mathrm{~m}^{3}$ fiberglass tanks at a stocking density of 6000 tank $^{-1}$, feeding with a starter diet, low water renewal rate, aeration and normal fluctuations of temperature, $\mathrm{O}_{2}$ and $\mathrm{pH}$. Next, 240 individuals were distributed into sixteen indoor $0.5 \mathrm{~m}^{2}$ tanks to test two rearing densities (20 and 40 animals $/ \mathrm{m}^{2}$ ) and two diets (a commercial diet and the experimental diet "special quarantine" of Experiment 1 (Table 1). Each treatment was replicated 4 times. At 167 days after post-larvae, all animals were fed the experimental diet "special quarantine" without changing initial stocking densities. Daily rations started at $10 \%$ and $8 \%$ of the biomass, respectively for the "special quarantine" and the commercial pellet to offset differences in moisture content between the two diets $(25 \%$ and $8 \%$ for the experimental and commercial diet, respectively. Rations were adjusted weekly based on growth, survival and observations of feed consumption. Survival and weight rate were measured every four weeks.

Animals were sexed and tagged by multiple injection of colored elastomer after the third month of the experiment. Individual growth rate was monitored thereafter. Concurrently, animals from the same larval rearing batch were reared in outdoor earthen ponds at the density of 10 animals per $\mathrm{m}^{2}$ and fed the commercial pellet (Table1).

\section{Experiment 3}

Prior to this experiment, larvae were raised in clear water with an inoculum of algae the first day, then with inert diet (microcapsules) and Artemia auplii which were distributed daily. Water was not changed during the whole larval period until PL's appeared (Aquacop \& Martin 1994). A hatchery population of $L$. vannamei was reared in clear water from hatching to $1-2 \mathrm{~g}$ average weight following a standard hatchery protocol (Aquacop 1982) Once the animals reached 1 to $2 \mathrm{~g}$ they were placed in sixteen $0.5 \mathrm{~m}^{2}$ tanks at 200 animals $/ \mathrm{m}^{2}$. 
A diet test was conducted during which mean survival was $67 \%$. To begin experiment 3 , individuals ( $\mathrm{n}=240)$ were weighed and stocked in fifteen $0.5 \mathrm{~m}^{2}$ tanks to test the effect of three rearing densities $\left(16,32\right.$ and 48 animals per $\left.\mathrm{m}^{2}\right)$; each density treatment was replicated five times. Fifteen weeks later, animals from the low, medium or high density were transferred into nine larger $1.2 \mathrm{~m}^{2}$ tanks at the density of 17 animals per $\mathrm{m}^{2}$. The animals were fed ad libitum the "special quarantine" collet (proper term for extruded feed). Daily rations were based on $10 \%$ of the biomass. Once a month, animals were weighed and counted to calculate growth and survival. Concurrently, animals from the same larval rearing batch were reared in outdoor earthen ponds following the protocol described above and fed the commercial pellet. This provided a control group to test reproductive performance of animals reared in clear water. Female reproductive ability was tested by mating them with males reared in outdoor ponds.

\section{Statistical analysis}

Statistical analysis consisted of an analysis of variance for growth (F Fischer test) and multiple range test to establish difference among treatments. Chi-square tests were used for survival data. Both tests were performed on Statview@ software. The confidence level was set at 5\%.

\section{Results}

\section{Experiment 1}

Survival rate for the period (120 days) ranged from $18 \%$ to $45 \%$. Chi-square tests on the numbers of living and dead animals per density showed no significant effect of density $(\mathrm{p}>0$. 05). Mortality was mainly due to the inefficiency of the nets located above the tanks to prevent shrimp from jumping out at night.

Daily growth rate in clear water averaged $0.14+/-0.04 \mathrm{~g}$ g/day for the 120 day period, while average growth rate in earthen tanks was $0.2 \mathrm{~g} /$ day (no individual data). Analysis of individual average daily weight gain in clear water indicated significant effects of sex in favour of females $(p<0.01)$ and of density in favour of low density $(0.15+/-0.04 \mathrm{~g}$ /day versus $0.13+/-$ $0.03 \mathrm{~g} /$ day) $(\mathrm{p}<0.05)$ (Table 2).

Table 2: Analyse of variance on individual weights L.stylirostris in experiment 1

\begin{tabular}{lccrrrrr}
\hline & d.f. & sum of squares & mean square & F value & $p$ value & lambda & power \\
\hline Sex & 1 & 0.015 & 0.015 & 13 & 0.0008 & 13 & 0.96 \\
Density & 1 & 0.005 & 0.005 & 4 & 0.04 & 4 & 0.53 \\
Sex x Density & 1 & $4.534 \mathrm{E}-4$ & $4.534 \mathrm{E}-4$ & 0.4 & 0.52 & 0.4 & 0.09 \\
Residual & 34 & 0.037 & 0.001 & & & & \\
\hline
\end{tabular}

In maturation tanks, females reared in clear water did not mature after eyestalk ablation, while control females reared in earthen ponds did. These ones were used to test the reproductive ability of the males reared in clear water. Fifty percent of the clear water males had a descent after insemination of a female reared in earthen ponds. While no significant difference of tested females was observed, the number of eggs and nauplii produced were not significantly different between the "clear-water" males and their control (Table 3). However a significant 
effect (Chi-square test) of the rearing protocol was found for males on hatching rates; an average of $34 \%$ for "standard animals" and 29\% for clear-water animals.

Table 3: Reproductive performances of males L.stylirostris reared in clear-water vs. "standard" males tested by mating with "standard" females in Experiment 1. Standard mean animals raised in ponds according to classic extensive technique (Aquacop, 1982).

\begin{tabular}{llllll}
\hline $\begin{array}{l}\text { rearing protocol } \\
\text { used for tested } \\
\text { males }\end{array}$ & $\begin{array}{l}\text { number } \\
\text { mating } \\
\text { tested }\end{array}$ & $\begin{array}{l}\text { average weight } \\
\text { of standard } \\
\text { females }(\mathrm{g})\end{array}$ & $\begin{array}{l}\text { number of eggs } \\
\text { per spawn } \\
\text { (x1000) }\end{array}$ & $\begin{array}{l}\text { number } \\
\text { nauplii } \\
\text { (x1000) }\end{array}$ & $\begin{array}{l}\text { average } \\
\text { hatching rate } \\
(\%)\end{array}$ \\
\hline standard & 9 & 44 & $237+/-50$ & $79+/-40$ & $34 \%$ \\
clear-water & 18 & 44 & $204+/-29$ & $60+/-29$ & $29 \%$ \\
\hline
\end{tabular}

\section{Experiment 2}

Survival rate in clear water for the period ranged from $52 \%$ to $70 \%$ and averaged $57 \%$. No significant effect of diet was detected, whereas density was significant $(p<0.05)$. Mean survival was $52 \%$ for tanks with 40 animals par $\mathrm{m}^{2}$ (Table 4a) and $66 \%$ for tanks stocked at 20 animals per $\mathrm{m}^{2}$. (Table $4 \mathrm{~b}$ ). Individual weight was significantly affected by the diet from P1 167 on $(\mathrm{p}<0.01)$, but not by rearing density (Table $4 \mathrm{a})$. The animals fed the experimental diet reach $15.8+/-5.2 \mathrm{~g}$ in average weight while animals fed the commercial diet reach only 8.9+/-3.0 g. At $\mathrm{PL}_{229}$, density started to have a significant effect on weights (Table 4b). Growth observed in earthen ponds was intermediate. Animals reared in clear water and fed the experimental diet performed best (data not shown) and at $\mathrm{PL}_{229}$, females start to begin the maturation process.

Table 4a : Analyse of variance of individual weights at $\mathrm{P}_{163}$ in experiment 2

\begin{tabular}{lccccccc}
\hline & d.f. & sum of squares & mean square & F value & $p$ value & lambda & power \\
\hline Sex & 1 & 67 & 67 & 3 & 0.05 & 3 & 0.48 \\
Diet & 1 & 1833 & 1833 & 103 & $<0.0001$ & 103 & 1.00 \\
Density & 1 & 3 & 3 & 0.2 & 0.63 & 0.2 & 0.07 \\
Sex x Diet & 1 & 62 & 62 & 3 & 0.06 & 3.5 & 0.44 \\
Sex x Density & 1 & 8 & 8 & 0.4 & 0.49 & 0.4 & 0.10 \\
Diet x Density & 1 & 8 & 8 & 0.5 & 0.48 & 0.5 & 0.10 \\
Sexe x Diet x Density & 1 & 34 & 34 & 1.9 & 0.16 & 1.9 & 0.26 \\
Residual & 150 & 2655 & 17 & & & & \\
\hline
\end{tabular}

Table 4 b: Analyse of variance of individual weights at $\mathrm{P}_{229}$ in experiment 2

\begin{tabular}{lccccccc}
\hline & d.f. & sum of squares & mean square & F value & $p$ value & Lambda & power \\
\hline Sex & 1 & 212 & 212 & 6 & 0.01 & 6.7 & 0.73 \\
Diet & 1 & 1444 & 1444 & 45 & $<0.001$ & 45.6 & 1.00 \\
Density & 1 & 228 & 228 & 7 & 0.008 & 7.2 & 0.76 \\
Sex x Diet & 1 & 171 & 171 & 5 & 0.02 & 5.4 & 0.63 \\
Sex x Density & 1 & 0.15 & 0.15 & 0.005 & 0.94 & 0.005 & 0.05 \\
Diet x Density & 1 & 0.05 & 0.05 & 0.002 & 0.96 & 0.002 & 0.05 \\
Sexe x Diet x Density & 1 & 15 & 15 & 0.5 & 0.48 & 0.48 & 0.10 \\
Residual & 126 & 3985 & 31 & & & & \\
\hline
\end{tabular}




\section{Experiment 3}

Survival rates in clear water averaged $82 \%$ for the first fifteen weeks in $0.5 \mathrm{~m}^{2}$ tanks. The difference between high densities (76\%) and low densities $(90 \%)$ was marginally significant ( $\mathrm{p}$ $=0.055)$. The average survival for the second period was $68 \%$. Individual weight was significantly affected by the three tested rearing densities. Low and medium densities $(0.15 \mathrm{~g}$ per day) performed better than high densities $\left(0.13 \mathrm{~g}\right.$ /day) during the first period until PL ${ }_{173}$ (Table 5).

Table 5 : Analyse of variance of individual weights of L.vannamei in experiment 3

\begin{tabular}{lrcrrrrr}
\hline & d.f. & sum of squares & mean square & F value & $p$ value & lambda & power \\
\hline Density & 2 & 119 & 59 & 13 & $<0.0001$ & 27 & 0.99 \\
Residual & 187 & 816 & 4 & & & & \\
\hline
\end{tabular}

During the second period when no density factor was tested, the average growth rate remained at $0.11 \mathrm{~g}$ per day in clear water and $0.15 \mathrm{~g}$ day in earthen ponds. Females matured after eyestalk ablation, but gonads remained whitish. No fertilisation could be obtained from females mated with males reared in outdoor ponds.

\section{Discussion}

In an island situation or a remote area, solving the problem of ingredients supply was a prerequisite prior to set a sustainable feed formulation to keep shrimp growing steadily without decline and then to boost capacity of females to enter gametogenesis. The study was conducted to test the concept of an indoor rearing of pre-breeders from the postlarvae stage at low density $\left(1 / \mathrm{m}^{2}\right)$ for quarantine purposes. A range of 10-40 shrimp / $\mathrm{m}^{2}$ is acceptable (Otoshi et al. 2001) but not viable in the conditions described here. Raising shrimp without substrate and without high losses associated with their cannibalistic tendency appears to be feasible if a substantial amount of feed is provided daily. In fact, feeding at a level of $10 \%$ biomass daily which would be too high in a grow-out system was successful with maturing shrimp. Moreover, the fact that it was provided as a moist pellet improved intake. As expected this feeding regime resulted in poor FCRs $(>15)$. Excess feed was removed daily to maintain water quality. In the system we tested, using fresh foods such as squid, troca, mussels, bloodworms or Artemia, would likely create water quality problems even though it creates optimal conditions for food ingestion and transfer of essential nutrients for gonads during the final maturation stage.

The quarantine system do not allow a water flow-through system. However, in captive rearing conditions, the most important aspect was to provide a balanced artificial diet to sustain growth rate and then gonadal development. Mating ability (Ogle 1994), spawning frequency (number of spawning ranks) of the females (Cahu, Guillaume, Stéphan \& Chim 1994), viability of the larvae and percent of eggs reaching the PL stage (Patrois, Cuzon \& Aquacop 1990) are criteria used to evaluate diets under closed laboratory conditions with recycled water.

Diet was the main factor inducing significant differences in growth and reproductive performances $(p<0.001)$. This is the first report to our knowledge of rearing shrimp in clear water, without bottom substrate, with artificial feed over a long period under experimental 
conditions at COP/Tahiti. Prior to this, the standard practice involved collecting shrimp after one year in earthen ponds, followed by mass selection, i.e., a selection of larger specimens in each reproductive period,. Gonadal maturation depend largely on feeding. Aquacop (1977); Moore, Sherry \& Montanez (1974); Primavera (1978); Middleditch, Missler, Hines, McVey, Brown, Ward \& Lawrence (1979); Beard \& Wickins (1980); Brown, McVey, Scott, Williams \& Middleditch (1980); Chamberlain \& Lawrence (1981) obtained maturation of shrimp in captivity with different species if fed ad libitum with mussels, oysters, squid, shrimp, crabs and worms sometimes together with a dry diet. Dry diets from commercial companies, or locally produced (Aquacop 1997) in the same conditions used in the present study, failed to enhance maturation. A diet with $47 \%$ protein fed to females led to appearance of maturation signs followed by a regression of the ovary (Aquacop 1997). To avoid ovary regression during the final stage of gametogenesis, rearing conditions must be optimized. Similar results were observed using a $60 \%$ protein diet, even with vitamin fortification. Dietary protein is not the sole nutrient related to successful maturation, other nutrients, such as essential fatty acids, are also necessary. A rapid degradation of labile lipids (HUFA's), and an oxidation of HUFA's during storage at $-22^{\circ} \mathrm{C}$ (Cahu et al 1994) would explain some previous failures in the maturation process. Due to the absence of natural food supplements in ponds used to rear broodstock shrimp when a closed system is used to rear the shrimp, nutrients found in natural food and often at low or absent levels in grower diets must be supplemented into the broodstock diet. Successful maturation was obtained while breeders were fed with fresh troca (Trochus niloticus). Fresh troca was found beneficial at end of gonadal maturation and quality and egg viability appeared high. Gonads from such molluscs could be responsible for such positive effect and this is on line with results obtained on peneids fed bivalves or prawns, gonads of which possess a lipid composition rich in HUFA's (Middleditch et al. 1979; Aquacop 1982, 1983). Fresh food (mussel) play a role not only on the quality of breeders during their final growing phase to reach breeder size but also on maturation.

The strategy described here for husbandry of breeders addresses the issues on long term, fresh food availability and the potential of introducing disease via fresh feed. Further it suggests a feasible way to rear late PL's stage in clear water to the stage where they can reproduce. This kind of experiment reveals the importance of using a formulated diet rich in protein (at least $50 \%$ ), enriched in triglycerides from marine sources, phospholipids at $2 \%$ and fortified with a mineral mixture. Diets PGN and 40ne performed as well or better than a commercial diet (Table 1). However, commercial diets are superior generally from a texture point of view, with higher water stability than a laboratory-prepared diet. From a nutritional point of view, experimantal diets should be higher in quality than commercial diets since they are formulated to meet the nutritional requirements of the maturing shrimp. Such diets contain high quality protein (Cuzon \& Aquacop 1998), a higher amount of fatty acids, in particular EPA, cholesterol up to $5 \%$, a more balanced amino acid profile, vitamins, especially vitamin $\mathrm{E}$ (Patrois, Levy, Cuzon \& Aquacop 1991), vitamin C, and mineral supplements. A good compromise could be to use a balanced diet distributed as frequently as possible by means of an automatic feeder. However, a ration table should take into account the energy needed for reproduction and littel information exist along this topic even though theoretical calculation was attempted (Cuzon, Lawrence, Guillaume, Gaxiola \& Rosas 2004). Key considerations for shrimp maturation diets are the time required for shrimp to reach a broodstock size and the time needed for the ovary to mature following eyestalk ablation. Colour of the ovary should be green, yellow rather than white, and color is directly in relation with dietary carotenoids content. Carotenoids and especially paprika at $2 \mathrm{~g}$ per $100 \mathrm{~g}$ squid can counteract pigment 
deficiency syndrome characterized by a loss of egg pigmentation, increase Zoea-I deformities, reduced Zoeal-I feeding and reduced Zoea-II survival (Wyban et al. 1995). Carotenoid supply from the diet could be limiting if broodstock diet does not contain enough $(50 \mu \mathrm{g} / \mathrm{g}$ astaxanthin, minimum) and the shrimp do not have access to natural food. For example, in Indonesia, a significant lower level of carotenoid content in muscle and hepatopancreas in farmed tiger prawn at high stocking density compared to wild caught shrimp was observed (Lamsamang, Pewnim \& Pewnim 1996). Establier-Torregrosa (1966) determined the carotenoid content of the ovary changed markedly during maturation of Plesiopenaeus edwardsianus from $20-40 \mu \mathrm{g} / \mathrm{gm}$ in the resting state to $430-518 \mu \mathrm{g} / \mathrm{gm}$ in mature ovaries; a result that showed the importance for this nutrient and the range of accumulation.

In terms of nutrition, a high protein diet promotes reproduction more efficiently than grower diets having lower protein levels. Use of protein sources such as wheat gluten, lactic yeast, soy protein concentrate, low temperature fishmeal and squid meal increase diet quality. Using such high quality ingredients increases diet digestibility. Squid meal is added to the diet because it stimulates ovary development. This has led to the concept of a gonadal factor (Mendoza 1997) as found for growth performance earlier with the squid growth factor (Cruz-Suarez, Ricque \& Aquacop 1992). Data useful to estimate the energy cost of maturation are scarce. DE can reach $19 \mathrm{~kJ}$ g-1 and in terms of dietary digestible energy available for growth, estimates of need are calculated at 11 Joules mg-1 live weight gain (Bureau, Azevedo, Tapia-Salazar \& Cuzon 2000). The balance between digestible protein and digestible energy (DP/DE ratio) will be higher than $27 \mathrm{mg} / \mathrm{kJ}$ DE (Cousin 1995). As an energy source and to provide essential omega-3 fatty acids, dietary lipid level should be increased to 18\% (Millamena 1996).A good lipid source, i.e. fish oil rich in polyunsaturated fatty acids (PUFA's), is essential. Among PUFA's, EPA (Middleditch et al. 1979) is highly related to ovarian maturation and egg quality, a correlation between fecundity and EPA is evidenced. The same is found with DHA, but no correlation exists with 20:4n-6 (Alava \& Kanazawa 1995). Rather than saturated fats such as pork lard, or from meat meal (Cuzon et al.1995) fish oil should be combined with lecithin rich in phosphatids (95\%). These nutrients benefit maturing shrimp provided that the $n-3 / n-6$ ratio is kept in a range between 2 and 4 to mimic the ratio of fresh marine products. Phospholipid and cholesterol content in sperm is used to assess the capacity of sperm to penetrate and deliver protein P35 for example, or to a dividing cell. In vertebrates, the cholesterol: phospholipid ratio ranges from 0.02-0.80 according to species and nutrition can affect this ratio (Labbé, Bussières, Guillouet, Leboeuf, Magistrini, Vidament 2000). In shrimp feed, this ratio is usually 0.5 but further attempts should be made to correlate this ratio with sperm quality and its ability to be frozen and recover potency after thawing.

Balanced mineral source with soluble phosphates (sodium and potassium), magnesium chloride and an available calcium source, such as calcium lactate, improved the mineral status of animals deprived of access to natural foods. Macro-minerals and trace elements are also necessary in special maturation diets (Shigeno, 1975).

Future, improvement of diets for clear-water shrimp quarantine facilities will include low leaching diets, along with the identification of an appropriate feeding rate set every day and distributed with automatic feeders. Quarantine facilities would involve water recycled systems, using a biofilter (Bedier, Soyez, Lemaire \& Guy 1989).

Further work should consider a method to keep animals enough time under quarantine (primary or tertiary) and with appropriate dietary additives supply such as squid factor, ecdysteroids, vitellogenin, gonadotropine, an adequate balance between nutrients such as arachidonic acid, cholesterol/phospholipid ratio, n-3/n-6 balance, ratio DHA/EPA. 


\section{Acknowledgements}

Authors want to express their gratitude to B. Finet, Th. Dao and G. Mai who participated in the study.. Their valuable contribution was essential in such long range experiments.

\section{References}

Alava V.R. \& Kanazawa A. (1995) The effect of nutrition on crustacean gonadal development and reproduction. In, Abstracts of the $5^{\text {th }}$ Intl working group on Crustacean Nutrition Symposium, Kagoshima University, Japan,1995.

Aquacop (1975) Maturation and spawning in captivity of penaeid shrimps: Penaeus merguiensis de Man, P. japonicus Bate, P. aztecus Ives, Metapenaeus ensis de Man and P.semisulcatus de Man. Proceedings of the World Mariculture Society 6, 123-132.

Aquacop (1977) Elevage larvaire de pénéides en milieu tropical. Publications Cnexo, Actes Colloque 4, 179-191.

Aquacop (1982) Penaeid larval rearing in the Centre Océanologique du Pacifique. In Handbook of Mariculture, vol.1: crustacean aquaculture, CRC Press Inc., Boca Raton, USA, 1983.

Aquacop (1983) Production of feeds to support shrimp farming in Tahiti (FP). $1^{\text {st }}$ Int. Biennal Conference Warm water aquaculture Crustacea, Brigham Young University, Hawaii, 9pp.

Aquacop \& Martin J.L. (1994) Shrimp farming in New-Caledonia. Workshop on Strategy for Technology Transfer in Aquaculture. AADCP/EEC Program Component 3, Puerto-Azul (Philippines), 14-18 November 1994.

Bachère E., Mialhe E., Noel D. Boulo V. Morvan A. \& Rodriguez J. (1995) Knowledge and research prospects in marine mollusc and crustacean immunology. Aquaculture 132(1-2), 17-32.

Beard T.W.\& Wickins J.F. (1980) Breeding of Penaeus monodon F. in laboratory recirculation systems. Aquaculture 20, 79-89.

Bedier E., Soyez C., Lemaire P. \& Guy C. (1989) Filtration biologique en circuit fermé adapté à l'élevage larvaire de pénéides. Rapport Interne Ifremer, $15 \mathrm{pp}$.

Blancheton J.P. (2000) Developments in recirculation systems for Mediterranean fish species. Aquaculture Engineering 22 (1-2), 17-31. 
Brown A, McVey J., Scott B.M., Williams T.D.\& Middleditch A.L. (1980) The maturation and spawning of white shrimp Penaeus stylirostris under controlled laboratory conditions.

Proceedings of the World Mariculture Society 11, 488-499.

Bureau D. P. Azevedo P. A Tapia-Salazar M. \& Cuzon G. (2000) Pattern and cost of growth and nutrient deposition in fish and shrimp: potential implications and applications. Vth International Symposium on Aquaculture and Nutrition.19/22 Nov. 2000, Merida, Mexico

Cahu C., Guillaume J.C., Stéphan G. \& Chim L. (1994) Influence of phospholipid and highly unsaturated fatty acids on spawning rate and egg and tissue composition in P.vannamei fed semi-purified diets. Aquaculture 126, 159-170.

Chamberlain G.W. \& Lawrence A.L. (1981) Maturation, reproduction and growth of Penaeus vannamei and Penaeus stylirostris fed natural diets Proceedings of the World Mariculture Society 12, 209-224.

Cousin M. (1995) Contribution à l'étude de l'utilisation des glucides et du rapport P/E chez P.vannamei et P.stylirostris. Thèse INA / PG.Paris, 201pp.

Cruz-Suarez L.E., Ricque D., \& Aquacop (1992) Effect of squid meal on growth of Penaeus monodon juveniles reared in pond pens and tanks. Aquaculture 106 (3-4), 293-299.

Cuzon G., Patrois J., Cahu C. \& Aquacop (1995) Some fundamentals of peneids breeders nutrition. In Proceedings III Congreso Ecuatoriano de Acuicultura, Guayaquil, Oct.Nov.,1995.

Cuzon G. \& Aquacop (1998) Nutritional review of Penaeus stylirostris. Reviews in Fisheries Science 6, 129-141.

Cuzon G.,Lawrence A., Guillaume J., Gaxiola G. \& Rosas C. (2004) Nutrition of Litopenaeus vannamei reared in taks or in ponds. Aquaculture (in press).

Dao T., Goyard E., Cuzon G., Bureau D., Seynave G. \& Aquacop ( 2002) Assessment of the responses to genetic selection for growth in Penaeus stylirostris under different diets. Poster World Aquaculture Society, Beijing, 23-27/04/02.

Establier Torregrosa R. (1966) Carotenoids of plant and marine animals, distribution of carotenoids in crustacean Plesiopenaeus edwardsianus. Investigationes Pesqueras, 30, $207-$ 222.

Finet B. (2002) Conditionnement en eau claire à deux densités de stockage de L.stylirostris: performances de croissance et de reproduction. Rapport Intechmer, IFREMER COP Tahiti, $30 \mathrm{pp}$.

Godin D.M., Carr W.H., Hagino G., Segura F., Sweeney J.N., \& Blankenship L. (1995) Evaluation of a fluorescent elastomer internal tag in juvenile and adult shrimp P.vannamei. Aquaculture 139, 243-248. 
Goyard E., Patrois J., Peignon J.M.,Vanaa V., Dufour R., Viallon J., \& Bedier E. (2002) Selection for better growth of Penaeus stylirostris in Tahiti and New Caledonia. Aquaculture 204 (3-4), 461-468.

Goyard E., Arnaud S., Vonau V., Bishoff V., Mouchel O., Pham D., Wyban J., Boudry P. (2003) Residual genetic variability in domesticated populations of the Pacific blue shrimp (Litopenaeus stylirostris) of New Caledonia, French Polynesia and Hawaii and some management recommendations. Aquatic Living Resources (16 (6), 501-508.

Harrison K.E. (1990) The role of nutrition in maturation , reproduction and embryonic development of decapod crustaceans: a review. Journal. of Shellfish Research 9(1), 1-28.

Labbé C., Bussières J.F., Guillouet P., Leboeuf B., Magistrini M., \& Vidament M. (2000) Aptitude du sperme à la congélation chez diverses espèces domestiques: rôle du cholestérol. Colloque INRA Toulouse, Octobre2000.

Lamsamang W., Pewnim A. \& Pewnim T. (1996) Difference in levels of carotenoid pigments in wild and pond reared black tiger prawn P.monodon (Fabricius). Abstract World Aquaculture Society Bangkok, Jan. 1996.

Lucien-Brun H. (1997) Evolution of world shrimp production: Fisheries and aquaculture. World Aquaculture Society 28(4), 21-33.

Lytle J.S., Lytle T.S. \& Ogle J.T. (1990) Polyunsaturated fatty acids profile as a comparative tool in assessing maturation diets of $P$. vannamei. Aquaculture 89, 287-299.

Mendoza R., Revol A., Fauvel C., Patrois J. \& Guillaume J.C. (1997) Influence of squid extracts on the triggering of secondary vitellogenesis in Penaeus vannamei Aquaculture Nutrition $3(1), 55-63$.

Middleditch B.S., Missler S.R., Hines H.B., McVey J.R., Brown A., Ward D.B. \& Lawrence A.L. (1979) Metabolic profiles of peneid shrimp: dietary lipids ans ovarian maturation. Journal of Chromatography 195(3), 359-368.

Millamena M.(1996) Reproduction of Penaeus monodon and nutrition constraints. Aquaculture 102(2), 98-101.

Mock C. (1977) An evaluation of potential shrimp virus impacts on cultured shrimp and wild shrimp populations in the Gulf of Mexico and Southwestern US Atlantic coastal waters. Report Joint Subcommittee on Aquaculture, 65pp.

Moore D.W., Sherry R.W. \& Montanez F. (1974) Maturation of Penaeus californiensis in captivity. Proceedings of the World Mariculture Society 5, 445-450.

Moss S.M., Otoshi C.A., Arce S.M., Argue B.J., Montgomery A.D., Nagamine, K.T. \& Zogbi P.R. ( 2001) Comparison of shrimp performance in a recirculating raceway versus a flow- 
through round pond. Aquaculture 2001: Book of Abstracts World Aquaculture Society, 143 J.M Parker Coliseum Louisiana State University Baton Rouge LA 70803 USA: 754 pp.

Ogle J.T. (1994) The effect of diet on mating in Penaeus vannamei. In Book of abstracts, World Aquaculture, '94, WAS Baton Rouge, LA.USA, pp. 315 (abstract only).

Otoshi C.A., Montgomery A.D., Look A.M., \& Moss S.M. (2001) Effects of diet and water source on the nursery production of Pacific white shrimp Litopenaeus vannamei. Journal of the World Aquaculture Society 32(2), 243-249.

Ottogalli L., Galinie C. \& Goxe D. (1988) Reproduction in captivity of Penaeus stylirostris over ten generations in New Caledonia. Journal of Aquaculture in the Tropics 3, 111-125.

Patrois J., Cuzon G. \& Aquacop (1990) Mise au point d'un aliment maturation, I.Comparaison de 3 aliments, cas de P.vannamei. Rapport Interne IFREMER COP Tahiti, 13pp.

Patrois J., Levy P, Cuzon G. \& Aquacop (1991) Mise au point d'un aliment maturation, II. Effet de la supplementation du Monogal en vitamine E, cas de P.vannamei. Rapport Interne IFREMER,10pp.

Penet L., Goyard E., Chim L., Cuzon G., Bureau D., Bédier E. \& Aquacop. (2001) Testing of two strains of L.stylirostris after six generations of selection for growth and correlative responses on other traits. In Book of Abstracts, World Aquaculture Society 2001, Lake Buena Vista, Florida, Jan.2001, p.748.

Primavera J. (1978) Induced maturation and spawning in five-month old Penaeus mondon. Aquaculture 13, 355-359.

Shigeno K. (1975) Shrimp culture in Japan. Association for International Technical Promotion, Tokyo, 153pp.

Statview@ software (1998) Abascus concept version 5.0.

Weppe M., Bonami J.R., Lightner D.V. \& Aquacop (1992) Demonstracion de altas cualidades de la cepa de P.stylirostris Aquacop SPR43 resistence al virus IHHN. In Calderon,J. and Sandoval,V. editors. Memorias del Primer Congreso Ecuatoriano de Acuicultura. CENAIM, Guayaquil, Ecuador, pp.229-232.

Wyban J., Martinez G. \& Sweeney J. (1995) Nauplii quality effects of Paprika in Penaeus vannamei maturation diet. Abstracts of the Fifth International Working Group on Crustacean Nutrition Symposium, Kagoshima University, Kagoshima Japan. 